\title{
An Assessment of Green and Non-Green Consumers Intention to Purchase Green Products in Malaysia
}

\author{
Phuah Kit Teng ${ }^{1 *}$ Siti Intan Nurdiana Wong Abdullah² Bernard Lim Jit Heng ${ }^{3}$ Kelly \\ Wong Kai Seng ${ }^{4}$
}

\author{
${ }^{1}$ Department of Marketing, Faculty of Accountancy, Finance and Business, Tunku Abdul Rahman University College, \\ Kampus Utama, Jalan Genting Kelang, 53300 Kuala Lumpur, Wilayah Persekutuan Kuala Lumpur, Malaysia. \\ ${ }^{2}$ Faculty of Business, Communication and Law, INTI International University, Persiaran Perdana BBN, Putra Nilai, 71800 \\ Nilai, Negeri Sembilan, Malaysia. \\ ${ }^{3}$ Centre for University of Hertfordshire Programmes, Inti International College Subang, Malaysia \\ ${ }^{4}$ Department of Agribusiness and Bioresource Economics, Universiti Putra Malaysia, 43400 UPM Serdang, Selangor \\ Darul Ehsan, Malaysia. \\ *Corresponding author. Email: phuahkt@tarc.edu.my
}

\begin{abstract}
Malaysian demands for green products are escalating due to health concern and green products are common in Malaysia due to various green campaigns in medias over the decades. Yet, the market saturation of green products remained at infancy stage in Malaysia. Therefore, ability to foresee the consumers' purchase intention on green products is crucial for marketers especially for those who promote products that emphasize animal well-being and environmentally conscious. Theory of Planned Behavior was utilized for this study on green products; and the results indicated that variables such as attitude towards environment and animal welfare, influence of green movement, environmentalist and friends and education level are important in influencing green consumers' purchasing intention on green products. In addition, age, education and income level, subjective norm such as family and green movement are crucial in determining the non-green consumers' purchase intention on green products.
\end{abstract}

Keywords: Behavioral, green and non-green consumer, green products, purchase intention, sustainability

\section{INTRODUCTION}

The global environmental issues had been a concern since 1970 s and is continually increasing among society [1]. In 1980s, there are several environmental issues and occurrences which harm the environment and human lives such as global warming, depletion of the stratosphere ozone layer, land erosion, acid rain noise and water pollution. These have caused the environmentalism to merge as spotlight once again due to its devastating effect [2]. It has become a tenacious concern on society when the environments being degraded. The main solution for these problems would be a change in human behavior and attitude towards preserving the environment.

Green concept had existed long time in Malaysia; however, Malaysian only concerned about issues like food safety, animal welfare and environmental protection after the establishment of sustainable development policies in regards of animal protection, food safety and environmental management. As a matter of fact, there was no green purchasing law and regulations until the enactment of the Environmental Quality Act in 1974 and formation of the Department of Environment in Malaysia. Exploitation of natural resources, poor sustainable development, little attention on environment protection, disregarding food safety concern and lack of animal welfare were evidenced in early years. Only recently that the ideal of sustainable development was emphasized by the Malaysian government.

Green consumers refer to consumers who prefer products that do not endanger human health or endanger the environment [3]. These people are willing to make changes in their purchasing and consumption behavior in order to be environmentally friendly and do not mind paying more for green products. In addition, these green consumers will behave accordingly in their daily lives in order to sustain the ecology in friendly manner [4].

In the current business model, green marketing is a growing trend for most entrepreneurs [5]. Handayani and Prayogo [6] explained that green marketing is a concept on product marketing by emphasizing materials that are harmless to the environment and green marketing focus on ecological awareness. The aims are to deliver environmentally friendly products in fulfilling consumers and society satisfaction. Nowadays, consumers have great concern on the environment and displayed behavioral attempt to be more 
environmental friendly in purchasing. Therefore, business organizations are encouraged to embrace green marketing in their business operation. In addition, many Malaysian entrepreneurial establishments are adapting green marketing strategies and utilized the environmental concern as a basis for competitive advantage initiative.

In the global market, demand for green products increased and green products can be found throughout different countries in the world [7]. However, the market growth for green product was restricted due lack of trust, lack of literacy on green products and misconception on green products among consumers [8]. Durif, Boivin \& Julien [9] had defined green products as product adaptation of recyclable materials which emphasized renewable, biodegradable and toxic-free material involving production. This implied that processes such as production, processing, manufacturing and marketing emphasized on reduction of environmental externalities throughout the product life cycle. Besides, the marketing efforts of introducing green products emphasizing environmental protection and animal welfare consciousness among consumers in Malaysia have gained interest and awareness in consumers' purchasing behavior. Despite that demand and consumption of green products has increased tremendously, the market growth for green products in Malaysia remained at infancy stage. In spite of the initiatives from the government agencies and private institutions, the issue remains on whether the attitude of green and non-green consumers towards environment protection and animal welfare has become an essential part of their daily life and become an influential factor in their purchase decisions.

\section{MATERIALS AND METHODS}

\subsection{Conceptual Framework}

By using the Theory of Planned Behavior (TPB) as the underlying theory for this study, researchers attempted to discover the green and non-green consumers' intention to purchase green products. Through the adoption of TPB, this study can predict and clarify a wide range of health and environmental related behaviors and intentions. This is because TPB can verify that behavioral achievement is generally related to both motivation (intention) and ability (behavioral control). TPB framework provides the assumptions that consumers' attitude, subjective norms and perceived behavioral control are the three relevant independent variables in determining the intention to purchase green products. Previous studies on TPB focus on explanatory of attitude, subjective norm and perceived behavioral control and limited in terms of scope coverage. In this study, the researchers are trying to cover more indicators for attitude and subjective norm in order to have better comprehension on consumers' intention when deciding to purchase green products. Figure 1 exhibits the conceptual framework of TPB focusing on green and non- green consumers in Malaysia and measuring their intention of buying green products.

The attitudes of consumers towards environment and animal welfare consist of the accumulated belief in their daily life. Numerous studies have indicated that consumer attitude especially environmental conscious is a good predictor of consumer's purchase intention towards ecofriendly products [10][11][12]. Subjective norm refers to the influential of family, friends, environmentalists and green society on consumers' purchasing decision on green products. According to a Kim et al. [13] and Smith and Paladino [14] found that subjective norm significantly influences eco-friendly food purchase behavior. Perceived behavioral control is defined as factors that influence the behavior in which the action is easy or difficult to perform [15]. Past studies have shown that perceived behavior control will influence consumer purchase intention towards eco-friendly products [16][17]. For this study, income was utilised as the perceived behavioral control factor. In addition, socio-demographic characteristic such as age, education level, marital status and gender will affect the independent variables of this study. All these factors will enhance the consumers' confidence and purchase intention when buying green products.

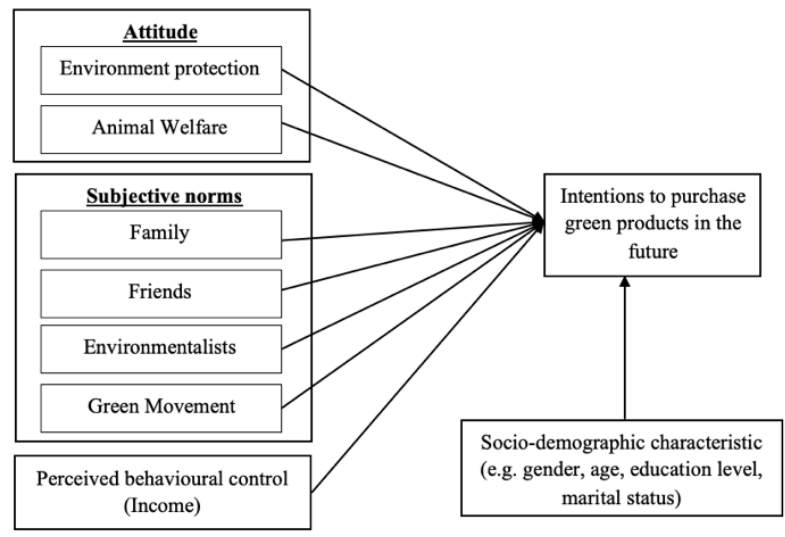

Source: Ajzen [15] Theory of Planned Behavior Figure 1 Conceptual framework of TPB in determining the purchase intention of green and non-green consumers when buying green products in Malaysia.

\subsection{Research Hypotheses}

The focus of this study was to find the factors which influenced green and non-green consumers' purchase intention towards green products. The following hypotheses were formulated.

Hypothesis 1: There is no significant relationship between the socio-demographic factors such as gender, age, education level and marital status with the green and nonconsumers' purchase intention towards green products.

Hypothesis 2: There is no significant relationship between consumer attitude (environment protection) with the green 
and non-consumers' purchase intention towards green products.

Hypothesis 3: There is no significant relationship between consumer attitude (animal welfare) with the green and nonconsumers' purchase intention towards green products. Hypothesis 4: There is no significant relationship between subjective norms (family) with the green and nonconsumers' purchase intention towards green products. Hypothesis 5: There is no significant relationship between subjective norms (friends) with the green and nonconsumers' purchase intention towards green products.

Hypothesis 6: There is no significant relationship between subjective norms (environmentalists) with the green and non-consumers' purchase intention towards green products. Hypothesis 7: There is no significant relationship between subjective norms (green movement) with the green and nonconsumers' purchase intention towards green products.

Hypothesis 8: There is no significant relationship between perceived behavioral control (income level) with the green and non-consumers' purchase intention towards green products.

\subsection{Sample and Questionnaire}

In this study, purposive sampling was selected and a total of 910 respondents (455 green consumers and 455 non-green consumers) were surveyed using structured questionnaires in order to measure their purchase intention on green products. Retail outlets like Cold storage, Tesco, Aeon, Giant, MyDin and Econsave were selected from each state in Malaysia as these outlets are considered as important venue for collecting data because most green products are widely available there. The structured questionnaire consisted four sections and utilized straight-forward questions. The measurement scale for each research variable for this study was seven-point Likert scale where 1 represented strongly disagree and 7 represented strongly agree.

\subsection{Method of Analysis}

To ensure the generalisability of the results, reliability analysis (Cronbach's alpha), descriptive statistic and binary logistic regression were utilized to determine the purchase intention of green products. Descriptive analysis summarized the quantitative data into a simple exhibit for easier understanding and measurement. Descriptive analysis is essential for the description on the population in this study. Furthermore, reliability analysis was conducted to determine the appropriateness and precision of the measurement for the variables used in this study [18].

In addition, binary logistic regression was applied in determining the extent to which selected sociodemographic characteristic, TPB variables influences green and non-consumers' intention to purchase green products in the future. For this study, green consumers referred to consumers who are presently purchasing and consuming green products. As for non-green consumers, these respondents consisted of consumers who do not purchase and consume green products. All the explanatory variables in this model have the value 0 or 1 . Dependent variable, $Y$ was depicted as 'intention to purchase green products in the future' and consist of 'green or non-green consumers' intent to purchase green products in the future'; which was coded as one and otherwise coded as zero. The different attitude, subjective norms and demographic variables are represented by $\mathrm{Xi}$ which can determine the consumers' intention. For this binary logistic regression model, the vectors $\mathrm{Xi}$ consist of the following variables: Attitude (animal welfare), Attitude (environmental protection), gender, age, marital status, education level, Perceived Behavioral Control (income level), Subjective Norm (family, green movement, friends and environmentalists). Specifically, the binary logistic model can be stated as below:

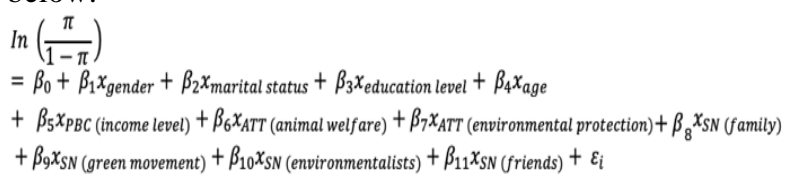

\section{FINDINGS AND DISCUSSIONS}

The value of Cronbach's alpha for the respective green and non-green consumers were 0.945 . This showed that there is consistency among the items used in theory of planned behavioral and deemed the model to be fitted for this study.

\subsection{Demographic Profile of Green and Non- Green Respondents}

Table 1 shows the demographic profile of the green and non-green consumers. Most of the green respondents were females $(52.5 \%)$ with more than half of them were married $(60 \%)$ and the majority were aged between $26-40$ years (46.8\%). In terms of education level, $71.7 \%$ of the green respondents have at least a tertiary education level. As for income level, about $44.8 \%$ of the green respondents have an income level between RM3,001- RM4,500 per month. For non-green consumers, most of the respondents were females $(56 \%)$ and it was more than the male (44\%). More than half of the non-green respondents were married (71\%) and majority of them were aged between 41-60 years $(42.2 \%)$. For education level, $68.8 \%$ of the non-green respondents have at least a tertiary education level and $42.9 \%$ of the respondents have an income level between RM1,501- RM3,000 per month.

\subsection{Binary Logistic Regression}

A binary logistic model was selected to determine the degree of the designated socio-demographic characteristics and attitudes in impacting the green and non-green consumers' future intention to purchase green products. The 
estimated parameters and statistical significance levels are shown in Table 2. The dependent variable 'intent to purchase green products in the future' had two categories of respondents. 'Consumers' who intend to purchase green products in the future' were coded as one and 'consumers' who do not do so were coded as zero.

Table 1 Socio-demographic profile (green consumer, $\mathrm{n}=455$; non-green Consumer, $\mathrm{n}=455$ )

\begin{tabular}{lccccc}
\hline Characteristic & $\begin{array}{c}\text { Green } \\
\text { Consumers (\%) }\end{array}$ & $\begin{array}{c}\text { Non-Green } \\
\text { Consumers (\%) }\end{array}$ & Characteristic & $\begin{array}{c}\text { Green } \\
\text { Consumers (\%) }\end{array}$ & $\begin{array}{c}\text { Non-Green } \\
\text { Consumers (\%) }\end{array}$ \\
\hline Gender & & & Income & & \\
Male & 47.5 & 44.0 & Below 1500 & 7.5 & 5.3 \\
Female & 52.5 & 56.0 & $1501-3000$ & 32.5 & 42.9 \\
Marital Status & & & $3001-4500$ & 44.8 & 37.4 \\
Single & 40 & 29.0 & $4501-6000$ & 7.9 & 7.7 \\
Married & 60 & 71.0 & Above 6001 & 7.3 & 6.8 \\
Education level & & & Age & & \\
Secondary & 9.2 & 20.5 & Below 25 & 18 & 4.8 \\
Tertiary & 71.7 & 68.8 & $26-40$ & 46.8 & 41.3 \\
Higher tertiary & 19.1 & 10.8 & $41-60$ & 32.1 & 42.2 \\
& & & Above 60 & 3.1 & 11.6 \\
\hline
\end{tabular}

According to the coefficients, the green consumers' attitude towards environmental friendliness is deemed as an important determinant for consumer intention to purchase green products in the future and the effect is positive (Table 2 ). The result indicated that consumers who possessed high environmental concerns were 2.449 times more likely to buy green products than consumers' who do not have concern on the environment. As for the estimated coefficient for consumers' attitude towards animal welfare, the value is positive and its significance was at 99 percent confidence level. This indicated that the likelihood of level of intention increases 2.665 times when the respondents are concerned about animal welfare, compared to respondents who have lack of concern on animal welfare. These results were consistent with the research conducted by Cheah and Phau [19] and Tong et al., [20] where consumers who had concern towards environment are more willing to purchase green product. Education level was the only sociodemographic characteristics with a positive sign and the significance level was at 99 percent confidence level. As such, respondents who possessed higher education level are 2.438 times more willing in purchasing green products than respective respondents who are not highly educated. The result was consistent with the study done by Silvia and Maria [21] and Wang et al., [22] where education level is one of the key determinants in influencing green purchase behavior. This result also showed that the green consumers under the influence of environmentalist, green movement and friends were 1.248 times, 1.325 times and 1.216 times respectively more willing to purchase green products in the future than those who have less influence by their environmentalist, green movement and friends. Some scholars also discovered that factors such as social norm and peer can influence individual's purchase behavior on green products [23] [24].

Furthermore, the study on non-green consumers' intention to purchase green products in the future discovered that only education level and income level impact their intention to purchase green products in the future. The findings exhibited that the intention of non-green consumers who are highly educated were 2.180 times higher in purchasing green products in the future than the non-green consumers who do not have high education level. As such, education level was also another relevant parameter that will impact consumers' green behavior [24]. This is due to the fact that someone with higher education level will have better analytical and judgment on the benefit of green concept. Besides, the results also indicated that non-green consumers whose income is higher were 2.930 times more willing to purchase green products in the future than the non-green consumers who do have high income. The study also exhibited younger group of respondents were 1.020 times more willing to purchase green products in the future than the older respondents. As green products are normally costlier than conventional products and the earning power of non-green consumers is lower than the green consumers, income was an important factor that influence green purchase behavior among the respondents. The study further indicated that the non-green consumers under the influence of their family and green movement were 1.161 times and 1.269 times respectively more willing in purchasing green products in the future than consumers who are not influenced. Similar outcomes were shown by Khare [25] and Afzaal et al., [26] as social norm from the 
perspective of peer and culture relevant factors can impact individual to select green products. In Table 2, the Homer and Lemeshow value for both green and non-green consumers were not significant. A non-significant value indicated that the model was fitted for this study. Using the tolerance and variance inflation factor (VIF), the results show that the tolerance for all independent variables was more than 0.1 and the value for VIF were less than 10 . Hence, there was no collinearity issues exist in the data.

\section{CONCLUSIONS}

Over the years, consumer awareness and public concerns on environment and animal welfare issues have increased and these were addressed in marketing. Therefore, the producers, processors and manufacturers were cautious on product offerings. However, the concept of green purchasing behavior raised concern among the general public because green concept is still new in Malaysia. This study attempted to address this issue by comparing the green consumers and non-green consumers. As green products became relevance in Malaysia, some consumers believed that green products could offer benefits like maintain the environment and protecting animal welfare compare to conventional products. One of the important criteria in enhancing consumer belief is informing the consumer on the benefit of purchasing and consuming green products. Consequently, local and international producers or manufacturers need to examine the ways consumers' selection of green and non-green products since there are difference in consumer behavior across countries. Ability to differentiate environmental friendly logos, green logos and animal welfare logos are likely to have positive impacts on the green products market potential. Without the ability to recognize the respective logos, the potential for green products is restricted because consumers may not able to differentiate the types of green and non-green product. Therefore, the governmental policy should prioritize qualified environmental friendly logos, green logos and animal welfare logos green in promoting green products by manufacturers or producers.

The present study is exposed to few limitations. One of the major limitations for this study is budget. This study focused on primary data which were collected from respondents who reside in Peninsular Malaysia. It is also relevant to study deeply on respondents from other states in Malaysia such as Sabah and Sarawak. Moreover, future research work is required to discover the consumer concern on fair trade when making decisions on purchasing food products. The importance of fair trade can help the producers in poor countries to compete with other established first world country.

This can be achieved through better trading conditions, promote sustainability environment, raising the awareness of their situation and campaigning. Although the market of fair-trade products may not be as big as the green products market, the market for fair-trade products is having higher percentage of growth compare to green products.

Table 2 Estimated logit model for green and non-green consumers' intention to purchase green products in the future

\begin{tabular}{|l|c|c|c|c|c|c|}
\hline & \multicolumn{5}{|c|}{ Green Consumers } \\
\hline Variables & $\begin{array}{c}\text { Estimated } \\
\text { Coefficient }\end{array}$ & $\begin{array}{c}\text { Standard } \\
\text { Error }\end{array}$ & $\begin{array}{c}\text { Significant } \\
\text { Level }\end{array}$ & Exp(B) & \multicolumn{2}{c|}{ Collinearity Statistics } \\
\cline { 3 - 7 } & -0.290 & 0.235 & 0.218 & 0.748 & 0.984 & 1.016 \\
\hline Gender & 0.208 & 0.337 & 0.537 & 1.231 & 0.473 & 2.114 \\
\hline Marital Status & 0.891 & 0.294 & $0.002^{* * *}$ & 2.438 & 0.616 & 1.624 \\
\hline Education Level & 0.006 & 0.014 & 0.676 & 1.006 & 0.476 & 2.099 \\
\hline Age & 0.429 & 0.297 & 0.148 & 1.536 & 0.644 & 1.553 \\
\hline PBC (Income Level) & 0.980 & 0.337 & $0.004^{* * *}$ & 2.665 & 0.947 & 1.056 \\
\hline ATT (Animal Welfare) & 0.896 & 0.290 & $0.002^{* * *}$ & 2.449 & 0.915 & 1.093 \\
\hline ATT (Environment) & 0.017 & 0.101 & 0.869 & 1.017 & 0.609 & 1.641 \\
\hline SN (Family) & 0.282 & 0.106 & $0.008^{* * *}$ & 1.325 & 0.682 & 1.467 \\
\hline SN (Green Movement) & 0.222 & 0.118 & $0.060^{*}$ & 1.248 & 0.671 & 1.490 \\
\hline SN (Environmentalist) & 0.196 & 0.112 & $0.082^{*}$ & 1.216 & 0.782 & 1.279 \\
\hline SN (Friends) & -7.406 & 1.053 & 0.000 & 0.001 & & 0.301 \\
\hline Constant & -2 Log Likelihood & 452.660 & Nagelkerke R Square & Hosmer and Lemeshow Test & 0.323 \\
\hline & Cox and Snell R Square & 0.213 & & \\
\hline & & & Non-Green Consumers & & \\
\hline
\end{tabular}




\begin{tabular}{|c|c|c|c|c|c|c|}
\hline \multirow[t]{2}{*}{ Variables } & \multirow{2}{*}{$\begin{array}{l}\text { Estimated } \\
\text { Coefficient }\end{array}$} & \multirow{2}{*}{$\begin{array}{l}\text { Standard } \\
\text { Error }\end{array}$} & \multirow{2}{*}{$\begin{array}{c}\text { Significant } \\
\text { Level }\end{array}$} & \multirow[t]{2}{*}{$\operatorname{Exp}(B)$} & \multicolumn{2}{|c|}{ Collinearity Statistics } \\
\hline & & & & & Tolerance & VIF \\
\hline Gender & -0.033 & 0.217 & 0.878 & 0.967 & 0.964 & 1.038 \\
\hline Marital Status & 0.051 & 0.291 & 0.860 & 1.053 & 0.623 & 1.606 \\
\hline Education Level & 0.779 & 0.248 & $0.002 * * *$ & 2.180 & 0.715 & 1.399 \\
\hline Age & 0.020 & 0.010 & $0.048^{* *}$ & 1.020 & 0.597 & 1.674 \\
\hline PBC (Income Level) & 1.075 & 0.274 & $0.000^{* * * *}$ & 2.930 & 0.754 & 1.327 \\
\hline ATT (Animal Welfare) & -0.017 & 0.289 & 0.953 & 0.983 & 0.942 & 1.061 \\
\hline ATT (Environment) & 0.236 & 0.287 & 0.411 & 1.266 & 0.922 & 1.084 \\
\hline SN (Family) & 0.152 & 0.084 & $0.072 *$ & 1.164 & 0.791 & 1.264 \\
\hline SN (Green Movement) & 0.238 & 0.091 & $0.009 * * *$ & 1.269 & 0.712 & 1.404 \\
\hline SN (Environmentalist) & 0.094 & 0.082 & 0.251 & 1.099 & 0.808 & 1.238 \\
\hline SN (Friends) & 0.037 & 0.083 & 0.658 & 1.038 & 0.671 & 1.490 \\
\hline \multirow[t]{3}{*}{ Constant } & -5.764 & 1.014 & 0.000 & 0.003 & & \\
\hline & \multicolumn{2}{|c|}{-2 Log Likelihood } & 519.782 & \multicolumn{2}{|c|}{ Nagelkerke R Square } & 0.214 \\
\hline & \multicolumn{2}{|c|}{ Cox and Snell R Square } & 0.156 & \multicolumn{2}{|c|}{ Hosmer and Lemeshow Test } & 0.392 \\
\hline
\end{tabular}

\section{REFERENCES}

[1] M. Laroche, J. Bergeron, Barbaro-Forleo, Targeting consumers who are willing to pay for environmentally friendly products. Journal of Consumer Marketing. 18(6) (2001), 503-520. DOI: https://doi.org/10.1108/ EUM0000000006155

[2] R. Ramlogan, Environmental and human health: A threat to all. Environmental Management and Health. 8 (2) (1997) 51-66. DOI: https://doi.org/10.1108/ 09566169710166548

[3] A.B. Tekade, S.S. Sastikar, Present green marketing: Importance and challenges in customer satisfaction. International Journal for Administration in Management, Commerce and Economics, 3 (2015) 308-312.

[4] S.P. Kalafatis, M. Pollard, R. East, M.H. Tsogas, Green marketing and Ajzen's theory of planned behavior: A cross-market examination. Journal of Consumer Marketing, 16(5) (1999) 441-460. DOI: https://doi.org/10.1108/07363769910289550

[5] W.W. Kassaye, Green dilemma. Marketing intelligence and planning. 19(6) (2001) 444-55. DOI: http://dx.doi.org/10.1108/EUM0000000006112

[6] W.Handayani, R.A. Prayogo, Green consumerism: An eco-friendly behavior form through the green product consumption and green marketing. Sinergi Jurnal Llmiah $\begin{array}{lllll}\text { Ilmu Manajemen. } 7 & \text { (2) (2017) 25-29 }\end{array}$ DOI: https://doi/org/10.25139/sng.v7i2.364

[7] S. Yogita, Changing consumer behavior with respect to green marketing- A case study of consumer durables and retailing. International Journal of Multidisciplinary Research. 1(4) (2001) 152-162.

[8] E. Yiridoe, Bonti-Ankomah, C. Ralph, Comparison of consumer perceptions and preference towards organic versus conventionally produced foods: A review and update of the literature. Renewable Agriculture and Food Systems. 20 (2005) 193-205. DOI: https://doi.org/10. 1079/RAF2005113

[9] F.Durif, C. Boivin, C. Julien, In search of a green product definition. Innovative Marketing. 6 (1) (2010) 25-33.

[10] M. Laroche, J. Bergeron, G. Barbaro-Forleo, Targeting consumers who are willing to pay more for environmentally friendly products. Journal of Consumer Marketing, 18(6) (2001), 503-520. DOI: https://doi.org/ 10.1108/EUM0000000006155

[11] N. Barber, "Green" wine packaging: Targeting environmental consumers. International Journal of Wine Business Research, 22(4) (2010), 423-444. DOI: https://doi.org/10.1108/17511061011092447 
[12] C. Tanner, S. Wölfing Kast, Promoting sustainable consumption: Determinants of green purchases by Swiss consumers. Psychology and Marketing, 20 (10) (2003), 883-902. DOI: https://doi.org/10.1002/mar.10101

[13] Y. J. Kim, D. Njite, M. Hancer, Anticipated emotion in consumers' intentions to select eco-friendly restaurants: Augmenting the theory of planned behavior. International Journal of Hospitality Management, 34(0) (2013), 255-262. DOI: https://doi.org/10.1016/j.ijhm. 2013.04.004

[14] S. Smith, A. Paladino, Eating clean and green? Investigating consumer motivations towards the purchase of organic food. Australasian Marketing Journal (AMJ), 18(2) (2010), 93-104. DOI: https:// doi.org/10.1016/j.ausmj.2010.01.001

[15] I.Ajzen, The theory of planned behavior, Organizational Behavior and Human Decision Processes. 50 (1991) 179-211. DOI: https://doi.org/ 10.1016/0749-5978(91)90020-T

[16] S. Rousseau, L. Vranken, Green market expansion by reducing information asymmetries: Evidence for labeled organic food products. Food Policy, 40 (0) (2013), 31-43. DOI: https://doi.org/10.1016/j.foodpol. 2013.01.006

[17] M. Miele, J. Lever, Civilizing the market for welfare friendly products in Europe? The techno-ethics of the Welfare Quality assessment. Geoforum, 48(0) (2013), 63-72. DOI: https://doi.org/10.1016/j.geoforum.2013. 04.003

[18] Y.F. Lay, C.H. Khoo, Introduction to computer data analysis with SPSS 16.0 for windows. Malaysia: Venton Publication, 2009.

[19] I.Cheah, I. Phau, Attitude towards environmentally friendly products: The influence of ecoliteracy, interpersonal influence and value orientation. Marketing Intelligence \& Planning, 29 (5) (2011) 452-472.DOI: https://doi.org/10.1108/02634501111153674

[20] Q.Tong, S. Anders, J. Zhang,L. Zhang, The roles of pollution concerns and environmental knowledge in making green food choices: Evidence from Chinese consumers. Food Res. Int., 130(2020) 108881. DOI: https://doi.org.10.1016/j.foodres.2019.108881

[21] C.Silvia, A.P. Maria, Sustainable consumption in the circular economy. An analysis of consumers' purchase intentions for waste-to-value food. J. Clean. Prod. 252 (2020) 119870. DOI: https://doi/org.10.1016/ j.jclepro.2019.119870
[22] X.Wang, W. Li, J. Song, H. Duan, K. Fang, W. Diao, Urban consumers' willingness to pay for higherlevel energy-saving appliances: Focusing on a less developed region. Resour. Conserv. Recycl. 157 (2020) 104760. DOI: https://doi.org/10.1016/j.resconrec.2020. 104760

[23] X.Qi, A. Ploeger, Explaining consumers' intentions towards purchasing green food in Qingdao, China: The amendment and extension of the theory of planned behavior. Appetite, 133 (2019) 414-422. DOI: https:// doi.org.10.1016/j.appet.2018.12.004

[24] P.Halder, E.N. Hansen, J. Kangas, T. Laukkanen, How national culture and ethics matter in consumers' green consumption values. J. Clean. Prod. 265 (2020) 121754. DOI: https://doi/org.10.1016/j.jclepro.2020. 121754

[25] A. Khare, Antecedents to green buying behavior: A study on consumers in an emerging economy. Mark. Intell. Plan. 33 (2015), 309-329. DOI: https://doi/org. 10.1108/MIP-05-2014-0083

[26] A.Afzaal, X. Guo, A. Adnan, S. Mehkar, M .F. Muhammad, Customer motivations for sustainable consumption: Investigating the drivers of purchase behavior for a green-luxury car. Bus. Strategy Environ. 28 (2019) 833-846. DOI: https://doi.org/10.1002/bse. 2284 